Branko Đ. Tošović*

profesor emeritus, Univerzitet Karl Franc, Grac, Institut za slavistiku

\title{
IVO ANDRIĆ I RUSKA KNJIŽEVNOST
}

U radu se razmatra mjesto ruske književnosti u stvaralaštvu Iva Andrića, ruski uticaj na njega, Andrićev odnos prema ruskim književnicima i njihovim djelima. U centru analize nalazi se interakcija Iva Andrića i stvaralaca zlatnog doba ruske proze (XIX vijek), te velikih ruskih pisaca XX stoljeća. Posebna pažnja posvećena je odnosu Iva Andrića prema Turgenjevu, Dostojevskom i Gorkom, a u značajnoj meri i prema Puškinu, Gogolju, Tolstoju, Čehovu i Šolohovu.

Ključne rïječi: Ivo Andrić, ruska književnost, ruski pisci i pjesnici, uticaj, interakcija.

O.

Ivo Andrić (1892-1975) rastao je i razvijao se pod uticajem različitih tokova u svjetskoj književnosti, u kojoj se po značaju djelovanja izdvajaju njemačka, francuska i ruska literatura. ${ }^{1}$ Svaka od njih pomogla je Andriću da trasira i uobliči književnu stazu, formira osobenu poetiku i napiše djela dostojna Nobelove nagrade.

Ruska književnost jedna je od najjačih i najuticajnijih nacionalnih literatura, a njen XIX vijek spada među najznačajnije i najplodnije periode $\mathrm{u}$ istoriji svjetske književnosti. Ovo zlatno stoljeće posebno je bilo plodno u prvoj polovini toga vijeka. Sve je počelo sa poezijom i prozom A. S. Puškina, djelima M. J. Ljermontova, basnama I. A. Krilova, a završilo se pjesmama F. I. Tjutčeva. U drugoj polovini centralne figure bile su N. V. Gogolj, L. N. Tolstoj, M. Dostojevski, M. J. Saltikov-Ščedrin, I S. Turgenjev, A. N. Ostrovski. Na razmeđu XIX i XX stoljeća djelovali su A. A. Blok, A. P. Čehov, M. A. Gorki, I. A. Bunjin. Zatim su došli V. V. Majakovski, S. A. Jesenjin, M. A. Šolohov, B. L. Pasternak, A. I. Solženjicin, J. A. Brodski... Oni su obogatili evropsku i svjetsku riznicu velikim proznim, pjesničkim i dramskim djelima, te izvršili snažan uticaj na mnoge pisce i pjesnike. To se odnosi i na Iva Andrića. Iz njegovih tekstova, razgovora i intervjua vidi se da je dobro

\footnotetext{
branko.tosovic@uni-graz.at

1 Tu bi se mogla dodati i poljska književnost.
} 
poznavao rusku književnost, da je mnoga njena djela čitao, neka i u originalu (znao je ruski jezik). I ne samo to: on se, direktno ili indirektno, na njih naslanjao, i po nekim ruskim obrascima gradio, mijenjao i usavršavao svoju poetiku. Postoji čitava galerija ruskih književnih stvaralaca koji se na ovaj ili onaj način mogu dovesti u vezu sa Andrićem. Među njima po jačini interakcije izdvajaju se F. M. Dostojevski i A. M. Gorki.

\section{2.}

Andrićev pogled na rusku književnost najglobalnije je došao do izražaja u govoru na večeri posvećenoj ruskoj književnosti (Andrić

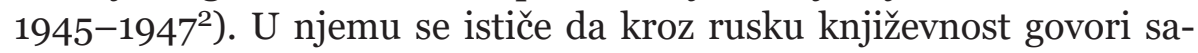
vjest čovječanstva, a da su njena klasična djela postala, kao opšte dobro, kameni miljaši u razvoju ljudske misli, dok su Oblomov, Hljestakov i Raskoljnikov ušli kao jasni i posve određeni „termini“ u rječnik „misaonog svijeta“. Andrić tvrdi da ruska književnost čitavo jedno stoljeće hrani i vodi čovječanstvo, ne zato što mu se hegemonistički nametnula, nego zato što sadrži u sebi, kao nijedna druga živa književnost, put ljudske misli i glas ljudskog srca. On smatra da bogatstvom i raznolikošću tema i širinom registra ruska literatura ima djela za sve ukuse i temperamente, a kao njene karakteristične crte izdvaja: bogatstvo problematike, smjelost i iskrenost rješenja, savršenstvo umjetničke obrade, visoko moralno osjećanje, široko razumijevanje sudbine čovjeka, jedinstveno shvatanje vrijednosti i svetinja ljudskog rada, stalnu težnju ka pravednijem poretku i boljoj i dostojnijoj sudbini čovjeka. Po tim osobinama ruska je književnost nadmašila sve književnosti svijeta, prešla granice svoje zemlje i svoga jezika, te postala učiteljicom svih naroda, svih ljudi koji teže napretku, boljim i savršenijim oblicima života. Andrić konstatuje da je već na početku XIX vijeka bilo jasno da je ruski narod predestiniran da iz svoje sredine dâ takvu književnost. Ruska literarna djela su po svojim temama i nadahnućima dolazila pravo iz ruskog tla i nalazila odjeka i razumijevanja kod gradskog stanovništva i inteligencije. Andrić povezuje dva velika vijeka ruske književnosti - XIX i XX - te ističe da je književnost prvog bila preteča, smjeli, često mučenički vjesnik onoga što je trebalo da dođe i što je sa Oktobarskom revolucijom 1917. godine zaista i došlo. Mišljenja je da književnost nove, sovjetske Rusije ne samo da nije iznevjerila istorijsku misao ruske književnosti nego se još jače uz narod vezala. Andrić korijene nove sovjetske literature vidi u staroj

2 Tekstualni primjeri uzimani su iz Andrićevog Gralis-Korpusa (stoga se ne navode strane). 
ruskoj književnosti obogaćenoj novim iskustvima, saznanjima i pogledima. Za njega je posve prirodno da je književnost u zemlji ostvarenog socijalizma prešla od kritičkog realizma na socijalistički realizam i da je u tome ostala vjerna dobroj tradiciji. Jer, ako je tačna Turgenjevljeva misao da književnost ima za cilj i objekat „živu životnu istinu“, onda je - nastavlja Andrić - nova sovjetska književnost mogla i morala da uzme za predmet stvarnost svoje socijalističke države. Ona je to i učinila, te postala hrana radnom i borbenom narodu u miru i ratu.

Andrić se u analizi poziva na tri naša velikana: Vuka Karadžića, Vatroslava Jagića i P. P. Njegoša. Za Vuka kaže da je napisao Kopitaru sljedeće riječi:

Ja ne znam ima li još gdje na svijetu da se ljudi o književnosti ovako trude i njom zabavljaju; kako god što se na starom Flajšmarktu govori i radi o trgovini, tako ovdje o literaturi.

Vatroslav Jagić, živeći u Rusiji, osjetio je, po Andrićevom mišljenju, budući preporod i veličinu ruskog naroda baš u vezi sa ruskom književnošću. Njegoš je umirući davao glavarima i preko njih narodu svoje posljednje savjete sa samrtničke postelje.

I u tom velikom trenutku, kad se istina dobro vidi i slobodno govori, on je, po kazivanju jednog savremenika, rekao Crnogorcima: „Držite se Rusije... i biće vam svako dobro!“

Andrić je govor završio riječima:

Mislim, drugovi i drugarice, da na kraju možemo i mi da kažemo i našoj čitalačkoj publici i našim književnicima: u književnosti, kao i u svemu ostalom, „držite se Rusije!“

\section{3 .}

Stvaralaštvo Iva Andrića i A. S. Puškina (1799-1837), između ostalog, podudara se i u tome što su obojica imala po jedan najkreativniji period. Za Andrića je to bio Drugi svjetski rat (kada je napisao i dovršio svoje najveće romane), a za A. S. Puškina boldinjska jesen (болдинская осень) 1830. I jedan i drugi obrađuju motiv škrtice, s tim što je kod Andrića posredi junakinja (Gospođica, Rajka Radaković), a kod Puškina muškarac - Vitez turdica [Скупой pыцарь]. Oba pisca imaju djelo u čijem se naslovu nalazi kriolema mećava: pripovijetka Dubrovačka mećava Iva Andrića i Mećava [Mетель] A. S. Puškina. Za beogradsko izdavačko preduzeće Kultura Andrić je na jednoj stranici recenzirao prevod Puškinove poezije koji je načinila Desanka Maksimović. Pritom je postavio načelno pitanje da li vrijedi drugačije 
prevoditi ovo Puškinovo djelo (Andrić 1994a: 106). Crnjanski je u prikazu Ex Ponta precizirao osjećanje i atmosferu djela kao obris slojevito umotane puškinovske i karamazovske tuge u govoru (Berbić Imširović 2019: 323).

4 .

U odnosu Iva Andrića i N. V. Gogolja (1809-1852) pada u oči podudarnost u sudbini dvaju romana: Proklete avlije i Mrtvih duša. Oba djela doživjela su osjetna skraćena - Andrić je Avliju dvostruko smanjio, a Gogolj drugi tom Mrtvih duša - spalio. Sâm Andrić konstatuje da je taj Gogoljev roman trebalo da bude znatno širi, a ispalo je sasvim drugačije: „I deo $M . D$. bio je tek deseti deo onoga što je trebalo da bude II deo" (Andrić s. d.). Andrić je detaljno analizirao prepisku N. V. Gogolja i iz nje, kao i iz niza njegovih djela - pravio izvode (njih ima najviše u odnosu na sve druge ruske pisce). Bilježio je interesantne misli i ponekad ih citirao, recimo, onda kada je govorio da voli da putuje u Bosnu, jer mu se u njoj uho smiruje i odmara na kratkim i razvučenim dužinama riječi i imena, koje je slušao u djetinjstvu, da bi zatim dodao: „Gogolj je za tu priliku imao dobru rusku reč 'nazvučatsja', što bi u grubom prevodu moglo da znači: snabdeti se zvukovima zavičaja“ (Jandrić 1982: 48). Već u svojoj 20. godini života Andrić je bio upoznat sa stvaralaštvom N. V. Gogolja, o čemu svjedoči i podatak da u pismu Milošu Vidakoviću iz Višegrada 15. jula 1912. spominje Gogoljevu komičnost (Andrić 2000: 20).3

\section{5.}

Kada su u pitanju paralele između Iva Andrića i drugih ruskih pisaca, treba izdvojiti sličnosti i razlike između Andrića i I. S. Turgenjeva (1818-1883). To je predmet šire analize Sava Penčića (Penčić 1981: 731-741), u kojoj su se iskristalisala dva osnova zaključka: a) po mnogim fundamentalnim svojstvima Andrić i Turgenjev su antipodi, b) između njih postoji određena srodnost, sličnost.

Različitosti se mogu rezimirati u osam tačaka:

a) Turgenjev se bavio živom i tekućom savremenošću sopstvene zemlje i sopstvenog naroda; Andrić se prevashodno bavio njihovom prošlošću.

b) Turgenjev je bio principijelno ravnodušan prema bilo kakvim istorijskim temama; Andrić je na njima izgradio najveći i

3 Više o odnosu Andrić ↔ Gogolj v. Батаева 1997; Glišić 2016: 258. 
umjetnički najznačajniji dio pripovjedačkog i romansijerskog opusa.

c) Turgenjev je bio građanski, društveno i idejno angažovani stvaralac, javni radnik, aktivni sudionik u aktuelnim društvenim i političkim dilemama svoga doba; Andrić je za svoje osnovno načelo proklamovao neučestvovanje u raspravama i problemima tekuće, konkretne životne i društvene svakodnevice.

d) Turgenjevljevo djelo je svojevrsna duhovna istorija njegovoga doba, široko okrenuta prema društvu u kojem je pisac živio; Andrićevo djelo je, sa manjim izuzecima, u sebe zatvoreni i sâm sebi okrenuti svijet u kojem nema prostora za bilo kakve subjektivne autorske ideološke ili društvene angažmane.

e) Turgenjev je pisao da bi pokrenuo i unapredio jednu konkretnu društvenu stvarnost; Andrić je najkrupnija i najznačajnija društveno-istorijska događanja prevodio u prostor umjetnosti, ona su za njega samo medij i materijal umjetničkog oblikovanja i mišljenja.

f) Dijametralno suprotne stvaralačke pozicije Iva Andrića iI. S. Turgenjeva imale su čitav niz logičnih reperkusija na stil, metod i prozni postupak jednog i drugog autora, na izbor teme, funkciju naratora, posebno na izbor i model junaka.

g) Turgenjeva je zanimao prevashodno junak subjektivne projekcije, snažna i posebno označena individualnost; Andrić se najčešce bavio takozvanim likom-funkcijom, junakom-nosiocem državne moći, simbolom snage i autoriteta državne vlasti.

h) Dok je ideološka i društvena akcija Turgenjevljevog junaka, romantičara i zanesenjaka, uperena protiv autoriteta i simbola državne moći i moći vlasti (u osnovi njegovog angažmana stoji snažna potreba za ličnim čuvstvenim ostvarenjem, za ličnom srećom), čuvstveni život Andrićevih junaka odvija se na periferiji njihovog državnog i istorijskog misionarstva, najčešce kao deformisana čuvstvenost, kao mutna i animalna strastvena izopačenost.

Srodnost se manifestuje u sljedećem:

a) Oba pisca karakteriše isto zajedničko svojstvo - tragična sudbinska označenost, u konačnom ishodu - fatum smrti; tragični osjećaj svijeta kod Andrića je univerzalan, a kod Turgenjeva je prije svega došao do izražaja u jednoj posebno označenoj liniji njegovoga stvaralaštva koja se začela vrlo rano.

b) Beskraj vasione, vječno vreme neprekidnog trajanja istorije, predmeti neuništivog ljudskog neimarstva - i kod Turgenjeva 
i kod Andrića mjera su ljudske sudbine i ljudskih poduhvata, simbolična slika njihove kratkovječnosti, trošnosti i prolaznosti.

c) Vječno je izvan konkretne, pojedinačne ljudske sudbine koju Turgenjev i Andrić slikaju, koja je unutrašnjim ustrojstvom predodređena za tragičan ishod, i isti smisao imaju kama, koja sustiže graditelja višegradske ćuprije Mehmed-pašu Sokolovića, i lapis, kojeg u datom trenutku nije bilo da Bazarov izgori smrtonosnu ranu.

d) U naponu moći i razmahu snage uvijek postoji nekakva nepredvidljiva, banalna i fatalna pojedinost koja sjenku tragične ironije i kod Turgenjeva i kod Andrića baca upravo na one likove koji su nosioci moći ili ideje moći, koji su zaželjeli nešto više i napravili neko prekoračenje bilo u pravcu zla, kakav je često slučaj sa Andrićevim junacima, ili u pravcu plemenitog zanosa, koji karakteriše junake Turgenjeva. Ta prekoračenja se i u jednom i u drugom slučaju vrše u odnosu na jednu u imaginaciji sazdanu ideju o prirodnim i dopustivim granicama čovjekove moći.

e) Ljudska snaga izvan tih prirodnih i dopustivih granica, prema Andriću, sama u sebi nosi klice sopstvene propasti, a pretjerani zanos i polet Turgenjev nije oprostio ni tako bezazlenom junaku kao što je Pavluša iz Bežine livade.

f) Oba pisca njegovala su pjesme u prozi - Turgenjev Senilije, a Andrić prozno-lirske zapise Ex Ponto, Nemiri i Nesanice; ova djela, sasvim srodna po formi, po stilsko-kompozicionoj strukturi, imaju istu namjenu i donekle istu sudbinu, s tim što su Andrićeve „male proze“ nastale na početku, a kod Turgenjeva na kraju stvaralačkog puta.

g) Najčešći, u izvjesnom smislu čak i konstantni motivi Turgenjevljevih i Andrićevih pjesama u prozi jesu osjećanje usamljenosti, osjećanje apsurda, besmislenosti života, straha, i na kraju - smrti.

h) Motiv usamljenosti razliven je po cijelom stvaralaštvu Andrića i Turgenjeva.

i) Izlaz iz „neopisivog užasa“ bila je meditacija o smrti koja je takođe zajednički motiv Andrićevih i Turgenjevljevih malih proza. Motiv smrti u Andrićevoj zbirci Ex Ponto i Turgenjevljevoj Senilije sastavni je dio diskretno izraženog, ali neosporno prisutnog istorijskog konteksta sa prizorima stvarnih smrti, koji su i jednog i drugog umjetnika navodili na duboka razmišljanja. Kod Andrića je to Prvi svjetski rat, kod Turgenjeva Ruskoturski rat 1878. godine. 
F. M. Dostojevski (1821-1881) jedan je od stožernih pisaca u odnosu Andrić $\leftrightarrow$ ruska književnost. Andrić je, tumačeći individualnu i kolektivnu svijest - stupio u filozofsko-književnu interakciju sa Dostojevskim. Za Andrića je ovaj pisac, uz Tomasa Mana - najkrupnija figura na razmeđu XIX i XX vijeka, jer je sa njima, kako kaže, počela nova evropska književnost (Jandrić 1982: 189). Naš je pisac baštinio od F. M. Dostojevskog i Tomasa Mana, prema sopstvenom priznanju, krajnje racionalan, štedljiv i funkcionalan odnos prema deskripciji (Trnavac Ćaldović 2016: 756). Andrić nije posebno isticao nijednu knjigu F. M. Dostojevskog, jer su mu sve bile „podjednako lepe i umetnički ujednačene" (Jandrić 1982: 190). Njega su najviše uzbudili Zapisi iz mrtvog doта (Записки из мертвого дома), Piščev dnevnik (Дневник писателя) bio mu je vrlo zanimljiv, dok je u mladosti drhtao nad Zlim dusima (Бесы) (isto: 190-191). Andrić je priznavao da je na njegovo stvaralaštvo uticao ovaj ruski pisac, ali nikada nije mogao da kaže u kolikoj mjeri (isto: 189]. To se posebno odnosi na opis prirode: Dostojevski je među prvima u svjetskoj književnosti zapostavio pejzaž, fizički izgled i odjeću junaka, jer je za njega duša bila najprivlačniji pejzaž (isto). Andrić priznaje da je opis predjela potisnuo pod izvjesnim uticajem Dostojevskog i Mana, opisujući ga samo u onoj mjeri koliko je potrebno da se shvati sudbina čovjeka i njegovog djelovanja, smatrajući da je priroda onaj okvir u koji treba da se smjesti čovjek i njegova misao. Dostojevskog je uz Kafku Andrić izdvajao među evropskim i svjetskim piscima, jer, po njegovom mišljenju, njih dvojica čine, „bez sumnje, kapiju nove književnosti, ne samo u Evropi, već i u celom svetu“ (isto: 314). Oni su poznavali svoj zanat, a u literaturi malo je takvih majstora (isto: 316). Dostojevskog Andrić ubraja u red onih pisaca koji su cijelim svojim bićem i bez prestanka, bili odani književnosti (isto: 191). Naš pisac posebno ističe radinost Dostojevskog, koji je pisao kao pravi robijaš: on je, poput Kafke i Flobera, znao da bdije nad svojim djelima i po šesnaest sati. „Bezmalo da im u tome niko nije ravan u svetu, čak ni Balzak, koga bije glas da je danonoćno sedeo za pisaćim stolom" (isto: 191). Stoga mu je čudno da su neki protiv Dostojevskog i Kafke (isto: 315). Ovaj posljednji opredijelio se za kolebanje kao put do cilja, što je, ističe Andrić, možda došlo od Dostojevskog.

Pored mnogo pozitivnog, Andrić je kod Dostojevskog nalazio i slabosti. Recimo 1919. čitao je njegove tekstove i došao do zaključka da ima stranica za koje bi bolje bilo da ih nikad nije napisao: „to su časovi niske podlosti koje ima svak, ali o kojima se ne smije pisati niti govoriti“ (Andrić 2000: 171). Koliko je bio zainteresovan za ovog ruskog 
pisca svjedoči i podatak da je iz Bukurešta 6. marta 1992. zamolio Svetislava Cvijanovića da mu pošalje Mladu ženu F. M. Dostojevskog koji je ovaj izdavač objavio 1921 (isto: 318). Andrić je cijenio prepisku Dostojevskog, a takođe Flobera i Kafke. U najužem spisku pisaca čija je djela Andrić preporučivao za čitanje, pored Dostojevskog, nalaze se još dva ruska pisca - Ilja Erenburg i Andrej Platonov, a od drugih: Kafka, Anri de Monterlan, Flober, Hari Martinson, Ejvind Jonson, Margerit Jursenar, Rože Marten di Gar, Viljem Fokner, Gete, Kjerkegor, Šekspir, Angas Vilson i dr. (Jandrić 1982: 9).

Nikola Milošević tvrdi da se umjetnička ostvarenja Andrića i Krleže veoma razlikuju po načinu umjetničkog oblikovanja i da se pandan takvoj razlici može naći još samo u stvaralaštvu Dostojevskog i Tolstoja (Milošević 1976: 179). Andrića i Dostojevskog spaja izvanredan pripovjedački dar, obojica su fokusirana na čovjekov unutrašnji svijet, obojica su u izvjesnoj mjeri i zagonetne ličnosti (Ivanova 2015: 279).

Kada je u pitanju sličnost konkretnih tekstova dvaju pisaca, izdvajaju se Prokleta avlija i Zapisi iz mrtvog doma istom temom (zatočeništvom intelektualaca). ${ }^{4}$ Andrićev traktat o apsolutnoj sreći Tome Galusa (Zanos i stradanje Tome Galusa) podsjeća na apsolutnu, ali i fatalnu sreću koja obuzima lik „idiota“ kod Dostojevskog pred epileptični napad (Grubačić 2019: 339). Djetinjstvo je Andriću, baš kao i F. M. Dostojevskom, vrijeme koje određuje sudbine ljudi (Liović 2019: 446).

Andrić ističe da je, sporeći se s mnogim protivnicima, Dostojevski, s pravom, ukazivao na "sveopštost i svečovječnost“ Puškinovog genija (Jandrić 1982: 327). Nakon konstatacije da tajne svojih djela pisci odnose u grob, Andrić dodaje da je to, možda, najiskrenije rekao Dostojevski povodom Puškina. Andriću je bilo žao umjetnika koji su stvarali u čamotinji, pa kao primjer navodi Dostojevskog. 5

\section{7.}

Iva Andrića i L. N. Tolstoja (1828-1910) povezuju, prije svega, istorijski romani. Kod oba pisca postoji isti motiv - Napoleonov rat protiv Rusije 1812, s tim što je u četvorotomnom romanu Rat $i \mathrm{mir}$ on obrađen u obliku prave epopeje, a u jednotomnoj Travničkoj hronici - fragmentarno kao odjek zbivanja sa ruskih prostora u uskoj

4 Više o tome v.: Ivanova 2015: 279-285.

5 O drugim aspektima interakcije Andrić $\leftrightarrow$ Dostojevski v.: Kalezić 1982; Prunkl 1981 (arhetipski lik kod Andrića i Dostojevskog); Stojnić 1979 (tematsko jedinstvo i strukturne razlike između Zapisa iz mrtvog doma F. M. Dostojevskog, Proklete avlije Iva Andrića i Grobnice za Borisa Davidoviča Danila Kiša); Vujnović 2005 (Andrićeva Anika i Grušenjka Dostojevskog). 
travničkoj dolini. ${ }^{6}$ Njeni ženski likovi imali su svoje individualne karaktere, sudbine i skrovite tamne strane, svaki na svoj način, kao srećne i nesrećne porodice L. N. Tolstoja (Nikolić 2019: 542). U govoru na večeri posvećenoj ruskoj književnosti, odmah poslije Drugog svjetskog rata - Andrić se, između ostalog, poziva na hrvatskog novinara Krunoslava Heruca, koji je u pismima iz Rusije došao do niza zapažanja i konstatacija o velikoj ulozi književnosti u Rusiji i književnosti Rusije u svijetu. A govoreći o jednoj knjizi Lava Tolstoja, koja je tada objavljena, rekao je:

On [Tolstoj] nam najjasnije predočava ono goruće pitanje kojim se sada sve rusko društvo zanima o odnošaju inteligencije prema narodu, o reguliranju ručnog i umnog rada (Andrić 1945-1947a).

I zaista, nastavlja Andrić, Tolstoj je već tada bacio u svijet veliku riječ, kad je rekao „da rad ne treba da bude strašilo za jedne i teška robija za druge, nego da on mora biti opšta, radosna stvar koja sjedinjava ljude“. (isto). Andrić je isticao da je Tolstoj, za razliku, od Dostojevskog i Gogolja, „dozvolio sebi da ne shvati Puškina“ (Jandrić 1982: 116). ${ }^{7}$

\section{8.}

Jedna od osnovnih podudarnosti između Andrića i A. P. Čehova (1860-1904) leži u njihovom stilu i načinu izražavanja. Oba autora su isticala kratkoću i lakoničnost kao bitnu odrednicu lijepog, uzornog načina izražavanja. Stoga nije slučajno da Andrić izdvaja Čehovljevu misao: „Treba pisati tako da riječima bude usko, a mislima široko." Sličan stav ima i prema Gogoljevom iskazu: „Do jednostavnosti treba narasti.“ Andrić je govorio da je veoma teško napisati kratku priču i tvrdi da je malo u svijetu velikih novelista, da se mogu na prste izbrojati: prije svega, to su Čehov, Mopasan, Babelj, Hemingvej, Platonov, koji je kod nas malo poznat (Jandrić 1982: 137). U vezi sa dramom Tri sestre A. P. Čehova Andrić je ostavio dužu zabilješku o tome kako je doživio njenu predstavu u moskovskom Hudožestvenom teatru (Andrić 1945-1947b: 10-11). Neki smatraju da sklonost ka uopštavanju objedinjuje Andrića sa A. P. Čehovom (Тарталя 1992: 14). ${ }^{8}$ Andrić zapaža odsustvo smisla za dramu kod Srba i Rusa (Jandrić 1982: 371, 377).

6 O dva pristupa Napoleonovoj eposi u romanima Rat i mir Lava Tolstoja i Travnička hronika Ive Andrića v.: Nedeljković 1985, a o dramama civilizacija u njima v.: Nedeljković 1986.

7 O drugim aspektima opozicije Andrić ↔ Tolstoj v.: Bojović 1980; Anonim 1992; Simić 1994 (Andrić - srpski Tolstoj); Nikolić 2019.

8 O odnosu Andrić $\leftrightarrow$ Čehov v. takođe: Đurčinov 1991; Ѓурчинов 1998; Koprivica 1989. 
9.

Maksim Gorki (A. M. Peškov, 1868-1936) imao je značajan uticaj u početnoj fazi Andrićevog stvaralaštva, u fazi sazrijevanja. To je jedan od rjeđih stranih pisaca kome je Andrić posvetio pažnju posebnim radom (pored Tomasa Mana, Adama Mickjeviča, Hajnriha Hajnea, Volta Vitmena, Anrija Bordoa, Hermana Vendela, Augusta Strindberga, Filipa Tomaza Marinetija, Gabrijela D’Anuncija). Na Gorkog Andrić je prvi put obratio pažnju 1919. godine ${ }^{9}$ tekstom „Gorki: Jedna godina revolucije“ (Andrić 1919a). U njemu se osvrnuo na članke objavljene 1917. u listu Gorkoga Novi život (Новая жизнь), a posvećene revoluciji u Rusiji. Ti tekstovi predstavljaju za Andrića kulturno-istorijske dokumente koji pokazuju pjesnikovu ličnost sa nove i simpatične strane. Gorkog naziva nekadašnjim pjesnikom bosonogih nihilista, pisca koji u članku „O kulturi“ vjeruje u progres čovječanstva i odgojnu moć kulture. Andrić sumnja u takav optimizam i smatra da ruski pisac zaboravlja koliko je bio „destruktivan rad decenija“, u kom je i sam imao udjela te dodaje: „A revolucija u Rusiji ide napred po Nečajevljevom receptu: 'Punom parom kroz močvaru.'“

Andrić će se Gorkom (a) vratiti nakon Drugog svjetskog rata člancima „Stvaralačka iskra“ (1946a), „Stvaralačka ruka“ (1946b) i (b) poslije dobijanja Nobelove nagrade (1961) tekstom „Moj prvi susret sa delom M. Gorkog“ (1964).

Rad „Stvaralačka iskra“ posebno treba izdvojiti zbog toga što u njemu Andrić potencira ono što spada među najvažnije motive njegovog stvaralaštva - s v j e t l o s t. ${ }^{10}$ Gorki se u radu posmatra u opoziciji tamno-svijetlo i ovo drugo ističe kao dominantni marker. Andrić je kao mlad pročitao romantične priče M. Gorkog i od tada je u njemu, „u sjaju rečenice“ Gorkoga - ostalo saznanje da je to „pisac koji teži za svetlošću i sam stvaralac svetlosti“. U to vrijeme naša i evropska kritika prikazivale su ovoga kao pisca „tamnih strana života“ i tvrdile da je njegovo iznošenje mračnog i ružnog života samo po sebi svrha, što Andrić smatra potpuno pogrešnim, jer se gubila iz vida prava piščeva namjera: Gorki je prikazivao tamne strane života, ali ne sa ciljem da ih ovjekovječi, nego da, nakon njihove umjetničke obrade, doprinese njihovom iskorjenjivanju, da na njima, kao na tamnoj pozadini, jače istakne svoju s vijetlu viziju boljeg života. Element svjetlosti Andrić nalazi i u tome što siromaštvo, poroci i stradanja koje

9 Iste godine Andrić je u Knjižeunom jugu štampao pod pseudonimom R. prikaz prvog toma autobiografije Maksima Gorkog Djetinjstvo (Детство) (Andrić 1919b).

10 To je posebno pokazao zbornik Andrićeva Sunčana strana (Tošović 2019). 
je slikao u prvim radovima - nisu Gorkog nikad potpuno obeshrabrivali, nego izazivali otpor i težnju ka boljem (Andrić 1946a).

Svjetlost Andrić ne nalazi samo u knjigama nego i samoj ličnosti ovoga pisca: Gorki je bio siromašni noćni čuvar na željezničkoj stanici, imao je težak život, pun očajanja i, ponekad, opterećen razmišljanjima o samoubistvu, ali je sanjao i o tome da učini neko slavno djelo, maštao je o svijetlim radostima života. Andrić otkriva svjetlost i u načinu stvaranja ovog pisca: tokom izgnanstva u zabačeni Arzamas (zbog napisa i revolucionarne aktivnosti) Gorki je do u duboko u noć radio. Slijedi ono što podsjeća na opis noći francuskog i austrijskog konzula u Travničkoj hronici: prozori M. Gorkog „su svetleli nad usnulom i mračnom varoši“, što su mjesne vlasti primale sa velikim podozrenjem. Andrić zaključuje da je u životu i djelu M. Gorkog uvijek tama, na kraju, rađala svjetlost (isto).

Pored svjetlosti Andrić ističe kod Gorkog osobeni postupak, naročitu psihološku tehniku kojom Gorki operiše: gotovo sve njegove radnje i sva filozofija pripovijedanja proizilaze iz životnih opozicija. Gorki sastavlja dvije suprotnosti, ali onako kako ih život sâm spaja. I ovdje dolazi motiv svjetlosti:

Tada svetlost obasja krug posve novih činjenica i prenese nas u posve nove, neslućene predele. To je put kojim pisac postaje stvaralac, jer: otkriti nam u toj njegovoj svetlosti ono što bez nje ne bismo nikad saznali ni poznali, znači isto što i stvarati.

Konačnim zaključkom dovodi se u vezu umjetnički postupak i motiv svjetlosti - stvaralačka iskra M. Gorkog gasne sa posljednjim proznim tekstom i posljednjom riječju (isto).

U drugom tekstu - „Stvaralačka ruka“11 Andrić se vraća na umjetnički postupak Gorkog: jednom, davno, neko ga je zapitao u čemu je tajna ovog ruskog pisca, na šta Andrić, po sopstvenom priznanju, nije umio da odgovori, ali je kasnije, iščitavajući piščevo djelo, često pomišljao na to i došao do zaključka da se ona krije u riječima koje je A. P. Čehov uputio mladom M. Gorkom 1898. godine povodom njegove pripovijetke $U$ stepi: „Vi ste plastični, tj. kad predstavljate stvar, vi je vidite i osećate pod rukama. To je prava umetnost!“ Andrić je dodao da su svi veliki realisti plastični. U vezi s time Andrić izdvaja kod Gorkog još jedan bitan motiv (pored svjetlosti) - ruke, što i u naslov izvlači („Stvaralačka ruka“). Andrić analizira jednu od najtežih i najizrazitijih pripovijedaka M. Gorkog Tugu [Тоска], u kojoj glavni junak nema nijedne ruke. Naš pisac konstatuje da su kod Gorkog u svakodnevnim prilikama i prizorima običnog života njegovih ličnosti - ruke

11 Tekst nastao povodom 10. godišnjice smrti Gorkog. 
ono što najviše govori o njima i o njihovom životu. Ruski pisac uvijek obraća pažnju na ruke svojih likova i pomoću njih ocrtava psihička stanja (Andrić 1946b). Može se pretpostaviti da se Andrić, direktno ili indirektno, naslonio na Gorkog u snažnom opisu Zimonjićevih ruku u nezavršenom romanu Omer-paša Latas.

Andrić se vratio Gorkom u tekstu „Utisci iz Staljingrada“ (Andrić 1947). U njemu ističe da je veliki problem odnosa čovjeka prema radu mogao naći svoje puno i pravilno rješenje tek sa ostvarenjem sovjetskog poretka.

U poznim godinama (1964) Andrić se ponovo sjeća (posljednji put) Gorkog i opisuje prvi susret sa njegovim stvaralaštvom i uopšte sa svjetskom književnošću. Andrić je išao u četvrti razred sarajevske gimnazije (imao je petnaest godina), kada je otkrio da u jednoj od knjižara postoji biblioteka za pozajmljivanje knjiga. Tu je došao do male sveske pripovijedaka M. Gorkog. Pročitao je Makar Čudru (Макар Чудра), Staricu Izergil (Старуха Изергиль) i druge priče. Bio je oduševljen, pa je odlučio da i sâm nešto slično napiše. Cio ljetnji odmor proveo je u tijesnoj i ubogoj sobi na Bistiku ili u malom parku pored Miljacke, radeći na pripovijetki. Kada je tekst bio gotov, zaželio je da nekome pokaže napisano, „kad ne mogu da je štampam i bacim u svet, kao što to čini ovaj veliki, nepoznati Rus koji se zove čudnim imenom Maksim Gorki“ (Andrić 1964). Izabrao je dvojicu drugova, koji su gutali knjige kao i on. Rezultat je bio porazan: obojica su našla da njegova pripovijetka ne valja ni pet para, da je lišena stvarne podloge i svakog smisla i, što je glavno, da predstavlja rđavu kopiju pripovijedaka M. Gorkog. Andrić je bio strašno pogođen, međutim, brzo je zaboravio svoje prvo, najveće književno razočaranje, pa je već naredne jeseni došao do novih knjiga i novih drukčijih djela M. Gorkog. „Izlečio sam se zauvek od lude misli da pišem pripovetke kakve piše Gorki“ (isto).

10.

Andrić smatra da je teško pravdati činjenicu da su Nobelova priznanja mimoišla takve velikane književnosti kao što su Gorki i Tolstoj (Jandrić 1982: 182). Neki izvori ukazuju na to da je Gorki imao priliku da čuje Andrićevo ime: u jesen 1927. godine u Berlinu Gorkom je o Andriću pričao srpski istoričar književnosti Stevan Janjić (Романенко 2000: 13). Andrić se na više mjesta poziva na misao Maksima Gorkog o tome da je plemenit zadatak biti na zemlji čovjek i da gordo zvuči riječ čovjek. Našem je piscu bila bliska misao M. Gorkog o Puškinu: 
„Treba učiti od Puškina. Bežite od onog ko vam kaže da je Puškin zastareo" (Jandrić 1982: 116).

11.

Značajna je interakcija Ivo Andrić $\leftrightarrow$ I. A. Bunjin (1870-1953). ${ }^{12}$

12.

Andrić ukazuje na dobar stil niza ruskih pisaca, prije svega A. P. Čehova i I. E. Babelja. On ističe da kod Babelja (1894-1940) nema nijedne suvišne riječi, što se postiže darom, marljivošću i dobrim poznavanjem jezika (Jandrić 1982: 43).

13 .

Andrić je veoma cijenio stvaralaštvo M. A. Šolohova (1905-1984). To je posebno izrazio nakon dodjele Nobelove nagrade M. A. Šolohovu 1965. Tim povodom Andrić je dao izjavu Radio Beogradu u kojoj, između ostalog, kaže da to priznanje u punoj mjeri zaslužuju i nagrađeno djelo, i njegov autor, i velika literatura kojoj oni pripadaju (Andrić 1965).

Andrić je bio kritičan prema motivima koji su bili osnova mnogih odluka Nobelove komisije, a koji su negativno uticali na kandidaturu i konačni izbor ruskih pisaca (Jandrić 1982: 180-182). Njegov stav može se sažeti u tri tačke:

a) Odbor za dodjelu Nobelove nagrade ogriješio se o Ruse, a favorizovao je Francuze. Šveđani su imali dvije slabosti: jednu prema Francuskoj u pozitivnom smislu, a drugu prema Rusima u negativnom smislu: brojnim su Francuzima nezasluženo dali nagradu, a mnogim velikim ruskim piscima uskratili je.

b) Odbor za dodjelu Nobelove nagrade griješio je posebno time što se suviše obazirao na politiku, što „nije lepo i što je moralo uneti neke nesporazume“ (isto). Politički motivisanim Andrić smatra dodjelu nagrade i nekim ruskim književnicima (Bunjinu, Pasternaku i Solženjicinu ${ }^{13}$ ).

c) Odbor je napravio fatalnu grešku nedodjeljivanjem Nobelove nagrade L. N. Tolstoju.

12 Više o njoj v. Čović 1992a; 1992b; Борисова/Джесур 2019; Чович 1995.

13 O Prokletoj avliji kao preteči Gulaga v. Petrov 1991. 


\section{4 .}

U odnosu Andrić $\leftrightarrow$ ruski pisci postoje i druge sličnosti. Budući da njihova analiza obimom prevazilazi zadate okvire rada, ovdje cemo samo kratko reći da je Andrić pravio izvode iz djela M. J. Ljermontova, F. I. Tjutčeva, O. E. Mandeljštama i dr., dopisivao se sa I. G. Erenburgom, L. M. Leonovom, K. M. Simonovom, B. N. Polevom, S. S. Smirnovom, Vjač. Vsev. Ivanovom, susretao se sa I. G. Erenburgom, N. S. Tihonovom, L. M. Leonovom, A. A. Surkovom, V. P. Kataevom, F. V. Gladkovom, B. L. Gorbatovom, imao kontakt sa književnim kritičarem Dmitrijem Lihačovom i dr. ${ }^{14}$

\section{Izvori}

a)

Lični fond I. Andrića. Beograd: Arhiv SANU.

Gralis-Korpus-www:AndrićevGralisKorpus.http://www-gewi.uni-graz.at/ gralis/korpusarium/gralis_korpus.html. [15. 10. 2019].

b)

Andrić, I. [Res.] (1919a). Maksim Gorkij: Jedna godina revolucije, Izdanje: Süddeutsche Monatshefte, Leipzig/München 1918. Zagreb: Književni jug, 2-3, 134-135.

Andrić, I. [R.] (1919b). Maksim Gorki: Djetinjstvo, Zabavna biblioteka, Zagreb [1918]. Zagreb: Književni jug, 6, 287-288.

Andrić, I. (s. d.). [Prepiska N. V. Gogolja]. Lični fond I. Andriča. IA 439. L. 7. Beograd: Arhiv SANU.

Andrić, I. (1945-1947a). [Govor na večeri posvećenoj ruskoj književnosti. Lični fond I. Andrića. Kutija 28. Br. 929. L. 10. Beograd: Arhiv SANU.

Andrić, I. (1945-1947b). [Predavanje o kulturnom životu i književnosti u SSSR-u]. Lični fond I. Andrića. Kutija 28. Br. 930. L. 21. Beograd: Arhiv SANU.

Andrić, I. (1946a). Stvaralačka iskra. Beograd: Jugoslavija - SSSR, 8, 8-9.

Andrić, I. (1946b). Stvaralačka ruka. Beograd: Naša knjižeunost, 6-7, 188189.

Andrić, I. (1947). Utisci iz Staljingrada. Beograd: Jugoslavija - SSSR, 24-25, $19-23$.

Andrić, I. (1952). Koja bi dela savremene svetske književnosti trebalo prevesti, Anketa. Beograd: NIN, 22. 06. [Lični fond I. Andrića. IA 740 L. 1. Beograd: Arhiv SANU.]

Andrić, I. (1964). Moj prvi susret sa delom M. Gorkog. Sarajevo: Pregled, 3, 218-220.

14 Odnos Andrić $\leftrightarrow$ Rusija razmatra: Тошович 2018, 2019. 
Andrić, I. (1965). [Izjava Radio Beogradu 9. decembara 1965]. Lični fond I. Andrića. IA 506. L. 2. Beograd: Arhiv SANU.

Andrić, I. (1975). „Nisam grof Tolstoj...“, Odlomak iz knjige Razgovori $i$ ćutanja Koste Dimitrijevića. Zagreb: Start, 164, 42.

Andrić, I. (1994a). Izdavačkom preduzeću „Kultura“, Beograd [recenzija prevoda Puškinovih tekstova koje je načinila Desanka Maksimović]. Andrić, I. Prevodilačka sveska. Novi Sad: Svetovi. 106.

Andrić, I. (1994b). Pisac govori svojim delom. Beograd: BIGZ.

Andrić, I. (2000). Pisma (1912-1973). Privatna pošta. Novi Sad: Matica srpska.

\section{Literatura}

Anonim (1992). Nobelova nagrada za jugoslovenskog Tolstoja i Homera Balkana. Gornji Milanovac: Dečje novine, 1200 [Tematski broj: Ivo Andrić: stogodišnjica rođenja], 12-13.

Berbić Imširović, M. (2019). Semiotika prostora i kontinuitet egzistencije u Prokletoj avliji i nedovršenom Andrićevom romanu Na sunčanoj strani. Andrićeva Sunčana strana / Andrićs Sonnenseite. Tošović, B. (ur./ Hg.). Graz/Beograd/Banjaluka: Institut für Slawistik der Karl-FranzensUniversität Graz / Narodna i univerzitetska biblioteka Republike Srpske / Svet knjige / nmlibris. 163-182.

Bojović, V. (1980). Jedno poređenje Ive Andrića i Lava Tolstoja. Travnik $i$ djelo Ive Andrića - zavičajno i univerzalno. Popadić, M. (ur.). Sarajevo: Veselin Masleša / Univerzitet, 49-59. // Bojović, V. (1984). Književna viđenja. Titograd: Univerzitetska riječ. 93-107.

Čović, B. (1992a). „Instinkt smrti“ kod Andrića i Bunjina. Novi Sad: Zbornik Matice srpske za književnost i jezik. 2, 213-228.

Čović, B. (1992b). Strukturni parametri poetike Ive Andrića. Prikaz knjige: Olga L. Kirilova. Između mita i igre, Moskva, 1992. Novi Sad: Letopis Matice srpske, 45o, 843-846.

Čović, B. (1993). Motiv „instinkt smrti“ kod Andrića i Bunjina. Titograd: Glasnik Odjeljenja umjetnosti Crnogorske akademije nauka i umjetnosti, 12, 243-262. // Čović, B. (2002). Književne paralele. Beograd: Vedes. $87-105$.

Čović, B. (1994). Konstruktivna dominanta kao postupak u realizaciji motiva instinkta smrti kod Ive Andrića i Ivana A. Bunjina. 22. naučni sastanak slavista u Vukove dane, 1: Ivo Andrić u svome vremenu. Beograd: Univerzitet u Beogradu, Filološki fakultet, Međunarodni slavistički centar. 129-40.

Čović, B. (2002a). O „signalima“ skaza u Andrićevoj Kući na osami u kontekstu izomorfnih narativnih modela moderne ruske proze (komparativni pristup). Književne paralele. Beograd: Vedes. 241-252. // Čović, B. (2007). Retorika. Banja Luka: Panevropski univerzitet „Apeiron“ za multidisciplinarne i virtualne studije. 256-264. 
Čović, B. (2002b). Folklorni elementi u strukturi slike Tihog Dona i Na Drini ćuprije Ive Andrića (ka poetici romana-epopeje). Književne paralele. Beograd: Vedes. 161-197.

Đukić Perišić, Ž. (2012). Pisac i priča: Stvaralačka biografija Ive Andrića. Novi Sad: Akademska knjiga.

Đurčinov, M. (1991). Andrić i Čehov. Beograd: Književnost, 92, 607-612.

Glišić, N. (2016). Očev zavet u svetu laži i obmane (motiv tvrdice u Andrićevom romanu Gospođica). Andrićevi Znakovi. Andrićs Zeichen. Tošović B. (ur./Hg.). Graz/Beograd/Banjaluka: Institut für Slawistik der Karl-Franzens-Universität Graz / Narodna i univerzitetska biblioteka Republike Srpske / Svet knjige / nmlibris. 251-262.

Ivanova, I. (2015). Prokleta avlija i Zapisi iz mrtvog doma. Andrićeva Avlija / Andrićs Hof. Tošović B. (ur./Hg.). Graz/Beograd/Banjaluka: Institut für Slawistik der Karl-Franzens-Universität Graz / Narodna i univerzitetska biblioteka Republike Srpske / Svet knjige / nmlibris. 279-285.

Jandrić, Lj. (1982). Sa Ivom Andrićem. Sarajevo: Veselin Masleša.

Kalezić, V. (1982). Andrić i Dostojevski. Beograd: Književna reč, 184, 17. // Novi Sad: Zbornik za slavistiku, 23, 83-88.

Kirilova, O. L. (1980). Gogolj i Andrić. Sarajevo: Odjek, $19,7$.

Koprivica, D. (1989). Čehov, Leonov, Andrić. Titograd: Ovdje, 236, 13.

Liović, M. (2019). Svjetlo i tama u pripovijetkama iz zbirke Deca. Andrićeva Sunčana strana / Andrićs Sonnenseite. Tošović B. (ur./Hg.). Graz/ Beograd/Banjaluka: Institut für Slawistik der Karl-Franzens-Universität Graz / Narodna i univerzitetska biblioteka Republike Srpske / Svet knjige / nmlibris. 433-449.

Milošević, N. (1976). Andrić i Krleža kao antipodi. Beograd: Slovo ljubve.

Nedeljković, D. (1985). Rat i mir Lava Tolstoja i Travnička hronika Ive Andrića: dva pristupa Napoleonovoj eposi. Novi Sad: Polja, 322, 469-471.

Nedeljković, D. (1986). Tolstojev Rat i mir i Andrićeva Travnička hronika pred dramom civilizacija. Beograd: Sveske Zadužbine Ive Andrića, 4, $165-178$.

Nikolić, A. (2019). Motiv svjetlosti u Andrićevom stvaralaštvu (Svjetlost, tama i ljepota Venecijanke, Jelene, Anike, Mare, Švabice, Rifke, Fatime i Lotike). Andrićeva Sunčana strana / Andrićs Sonnenseite. Tošović B. (ur./Hg.). Graz/Beograd/Banjaluka: Institut für Slawistik der Karl-Franzens-Universität Graz / Narodna i univerzitetska biblioteka Republike Srpske / Svet knjige / nmlibris. 527-544.

Penčić, S. (1981). Andrić i Turgenjev. Delo Ive Andrića u kontekstu evropske književnosti i kulture. Nedeljković D. (ur.). Beograd: Zadužbina Ive Andrića. 731-741. // Penčić, S. (1983). Poetika proze. Niš: Gradina. 155-169. // Penčić, S. (1998). Slovenske komparativne teme. Niš: Prosveta. 71-80.

Petrov, V. (1991). Prokleta avlija preteča Gulaga. Beograd: Politika, 27917, 18-19. 
Prunkl, E. (1981). Eine archetypische Gestalt bei Andrić und Dostoevskij. Delo Ive Andrića u kontekstu evropske književnosti i kulture. Nedeljković D. (ur.). Beograd: Zadužbina Ive Andrića. 721-729.

Simić, D. (1994). Andrić - srpski Tolstoj: kritičar Indipendenta o novom izdanju Na Drini ćuprije. Beograd: Politika, 28941, 16.

Stojnić, M. (1979). Tematsko jedinstvo i strukturne razlike (F. M. Dostojevski: Zapisi iz mrtvog doma, Ivo Andrić: Prokleta avlija i Danilo Kiš: Grobnica za Borisa Davidoviča). 7. naučni sastanak slavista u Vukove dane, 2: Roman u srpskoj književnosti u odnosu na jugoslovenski $i$ evropski roman. Beograd: Univerzitet u Beogradu, Filološki fakultet, Međunarodni slavistički centar. 289-306.

Trnavac Ćaldović, N. (2016). I daleko i duboko, ni tamo ni ovde: semantika prostora u Travničkoj hronici Ive Andrića. Andrićevi Znakovi / Andrićs Zeichen. Tošović B. (ur./Hg.). Graz/Beograd/Banjaluka: Institut für Slawistik der Karl-Franzens-Universität Graz / Narodna i univerzitetska biblioteka Republike Srpske / Svet knjige / nmlibris. 755-795.

Vujnović, S. (2005). „Femme fatale“ u karnevalizovanom svetu: Andrićeva Anika i Grušenjka Dostojevskog. Beograd: Txt, Studentski časopis za književnost i teoriju književnosti, 7/8 [Tematski broj: Junak], 86-94.

Vukićević, M. (1967). Andrićev Karađoz i Major Dostojevskog. Podgorica: Stvaranje, 6, 714-716.

Борисова, Е. / Джесур, К.. (2019). Унес и екстаз в междутекстовия диалог на Иван Бунин и Иво Андрич. Andrićeva Sunčana strana / Andrićs Sonnenseite. Tošović B. (ur./Hg.). Graz/Beograd/Banjaluka: Institut für Slawistik der Karl-Franzens-Universität Graz / Narodna i univerzitetska biblioteka Republike Srpske / Svet knjige / nmlibris. 201-223.

Романенко, А. (2000). Об Иво Андриче и его книгах. Андрич, И. Пътка. Избранная проза. Москва: Панорама. 5-18.

Тарталя, И. (1992). Обобщение опыта одного рассказчика. Стокгольмская речь И. Андрича О повестовани и рассказчие. Творчество Иво Андрича: миф, фольклор, история, литература. Кириллова, О. Л. (ред.-сост.). Москва: Ин-т славяноведения и балканистики РАН. 8-12.

Тошович, Б. (2018). Андрич и Россия. Славянский мир: язык, литертура, культура. Ремнёва, М.Л., и др. (отв. ред.). Москва: МАКС Пресс. $311-313$.

Тошович, Б. (2019). Иво Андрич и Россия. Славянский мир: язык, литература, культура. Ананьева, Н. Е., Остапчук, О. А., Якушкина, Е. И. (отв. ред.). Москва: Макс Пресс - Филологический факультет МГУ. $378-385$.

Чович, Б. (1995). Мотив „инстинкт смерти“ у Иво Андрича и Ивана Бунина. Москва: Славяноведение, 1, 61-68. 
Бранко Дж. Тошович

Профессор-эмерит Университета им. Карла Франца, Грац,

Институт славистики

\section{Иво Андрич и Русская литература}

$$
\text { - Резюме - }
$$

В статье рассматривается место русской литературы в творчестве Иво Андрича, русское влияние на него, отношение Андрича к русским писателям и их произведениям. В центре анализа находится взаимодействие Иво Андрича и литераторов золотого века русской прозы (XIX в.) и великих писателей XX столетия. Особое внимание уделяется отношению Иво Андрича к А. С. Пушкину, Н. В. Гоголю, И. С. Тургеневу, Ф. М. Достоевскому, Л. Н. Толстому, А. П. Чехову, М. А. Горькому и М. А. Шолохову.

Ключевые слова: Иво Андрич, русская литература, русские писатели и поэты, влияние, взаимодействие. 